\title{
The Implementation of the Principle of Sustainable Development in the Special Nature Reserve „Stari Begej-Carska bara" (Vojvodina, Serbia)
}

\author{
Vladimir Stojanović', Dragoslav Pavićc', Branko Ristanović' \\ Received: June 2008 | Revised: January 2009 | Accepted: January 2009
}

\begin{abstract}
Special nature reserve "Stari Begej - Carska bara" is one of the last remaining wetlands in Vojvodina. Essential natural assets - hydrographic characteristics, have undergone significant changes, because of which the Reserve is still endangered even today. To overcome these obstacles in the management of the Reserve, we have to turn to the idea of sustainable development, which should in addition to the ecological criteria comprise socio-cultural and economic criteria.
\end{abstract}

Key words: sustainable development, special nature reserves, Stari Begej-Carska bara

\section{Introduction}

Special Nature Reserve „Stari Begej - Carska bara” (Old Begej - Imperial Marsh) is situated in the western part of the central Banat, on the territory of the municipality of Zrenjanin. It stretches in the shape of the letter $S$ along Begej, in the immediate vicinity of Tisza, whose alluvial plateau it is situated on. The essential value of this protected area and one of the most important elements for preservation is its hydrography. The river Begej is important ecological and evolutionary element of the Special Nature Reserve „Stari Begej - Carska bara" despite the fact that it is not situated within its area. Stari Begej is a backwater of Begej which more or less flows parallel to Plovni Begej. The length of the backwater is $16 \mathrm{~km}$, the width is $24 \mathrm{~m}$, and the depth from 0.8 to $2.30 \mathrm{~m}$. Carska Bara covers the strip between the old embankment and Stari Begej, in the north part of the Special Nature Reserve. It is a still body of water of Begej, created during Holocene (Tomić, 1992). The length of the Swamp is $1500 \mathrm{~m}$, the width $700 \mathrm{~m}$, and the depth is from $0.90 \mathrm{~m}$ - in spring and beginning of summer, to $0.40 \mathrm{~m}$ - during summer.

Its ornithofauna is of great importance for the Special Nature Reserve. Among 250 bird species, out of which 140 species of nesting birds are globally endangered species from the World and European Red Lists, such as Whiteheaded Duck (Oxyura leucocephala), Lesser White-fronted Goose (Anser erythropus), Pygmy Cormorant (Phalacrocorax pygmaeus), Dalmatian Pelican (Pelecanus crispus), White-tailed Eagle (Heliaeetus albicilla), Corn Crake (Crex (rex), as well as the species endangered in the Pannonian plain (Budakov, Branković, Sekulić, 1998).

The total area of the Reserve is $1.676 \mathrm{ha}$, and its borders are defined by the Preservation Bill for the Special Nature Reserve "Stari Begej-Carska bara", verified by the Government of the Republic of Serbia.

According to its prevailing characteristics, this type of scenery belongs to so-called wetlands. These areas, as the regulators of water regime and habitats of numerous plant and animal species, are intersected with particularly vulnerable ecosystems. Furthermore, the tendency of their disappearance through drainage and regulations, is predominant in this part of Vojvodina as well as in other regions. This is why, their preservation should be given a special attention. One of the ways is to apply the idea of sustainable development which would at the same time emphasize the protection, economic and socio-cultural development within the borders of the Reserve and its surroundings. (Stojanović, 2005) 


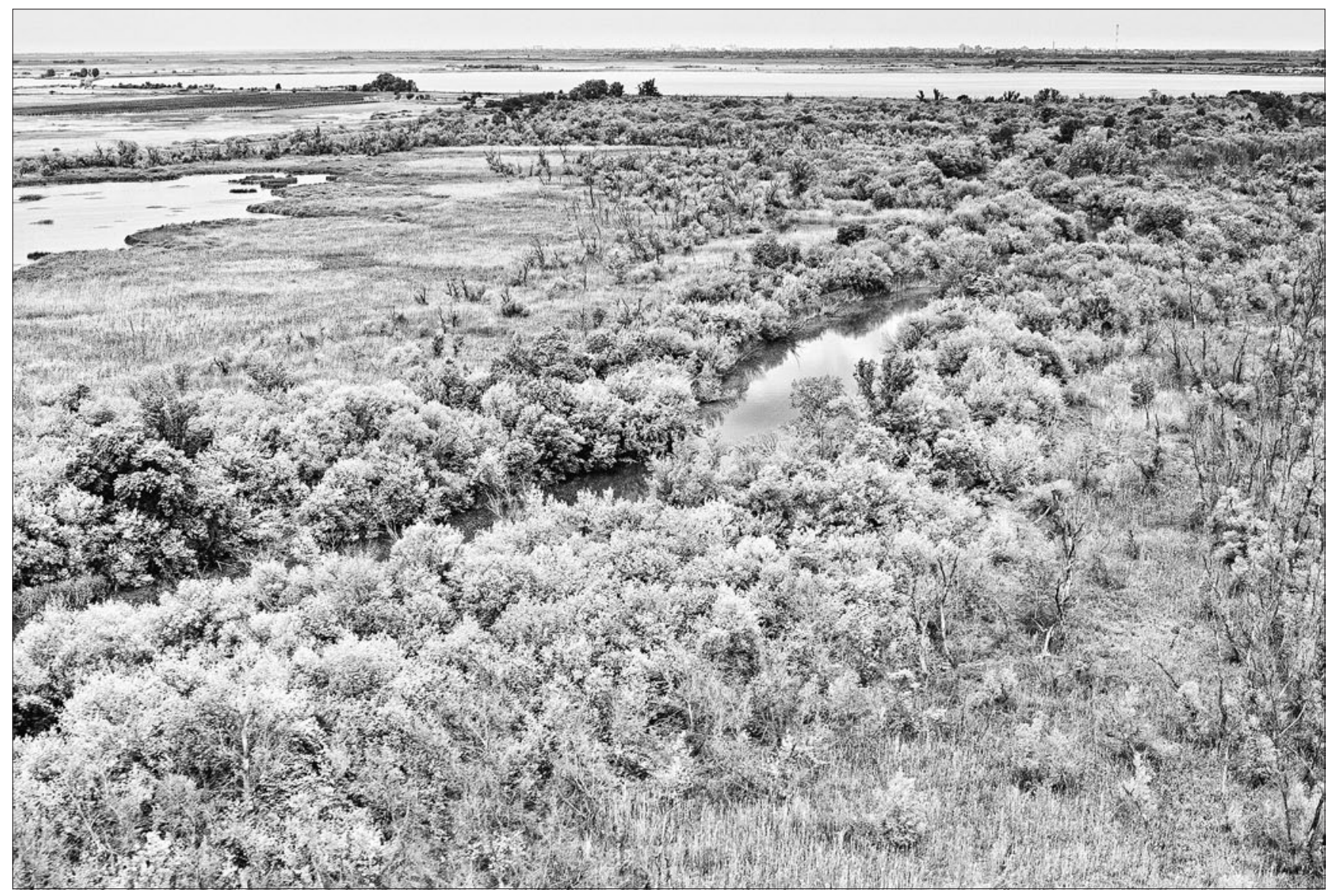

Figure 1 Special Nature Reserve „Stari Begej - Carska bara” - unique wetland area; Photo by: L.Lazić

\section{The protection as a condition for the ecological principle of sustainable development}

The first decision about the protection of the region was made in 1955 when „Vojtina mlaka” was protected for its exceptional natural beauty according to the Natural Heritage and Rarity Protection Law. The next legal act about protection followed in 1986 when the Municipality Government of Zrenjanin made a decision to proclaim the Regional Park "Stari Begej” and the Special Nature Reserve „Carska Bara" (Budakov et al., 1993). According to the Regulation of the Government of the Republic of Serbia, and on the initiative of the Institute for Nature Protection of Serbia, the Regulation about the protection of the Special Nature Reserve „Stari Begej - Carska bara” was proclaimed in 1994.

Special Nature Reserve „Stari Begej - Carska bara” is on the list of swampland regions of international importance according to Ramsar Convention.

On the territory of Special Nature Reserve, the first, second and third degrees of protection have been established (figure 1).

The protection regime of the first degree has been established on the area of 704 ha and covers Carska Bara with Vojtina Mlaka and the southern meander, Perleska Bara, Tiganjica and the part of Botoški Rit with patches of meadows and steppes.

The protection regime of the second degree has been established on the flow area of Stari Begej with the northern meander and the strip $10 \mathrm{~m}$ wide along the left bank of Tiganjica and Perleska Bara, Zagnjenica, Ravenica, Vi- soke grede, Male grede and Saračica. It covers the area of $372 \mathrm{ha}$. The forbidden activities are as follows: forestation of meadows, turning swampland and swamps into dry land areas, importing foreign flora and fauna, water pollution, harvesting and usage of the protected plant and animal species, fishing and hunting, except when needed for the preservation of the optimum number of animals and protection against contagious diseases, usage of motorboats, usage of pesticides, investment contracting, except for the works aimed at the implementation of the general protective measures.

In the same regime of the protection the following activities are provided: sanitation and regulation fishing and hunting, usage of reeds and cattail, sanitation wood cutting and willow trimming, conditions for the establishment of the optimum water regime.

The protection regime of the third degree covers the area of 600 ha. It includes parts of Farkaždinski and Botoški Rit with the strip $50 \mathrm{~m}$ wide and the area of Botoški Rit. In this area it is forbidden to pollute and change optimum water regime, to use pesticides, to contract investments which are not serving general protective measures.

Special Nature Reserve is surrounded with the protected area of 7.532 ha. In the area it is forbidden to start waste disposal sites, to perform works and activities that pollute the soil, air and water and change optimum water regime. It is allowed to use reeds, forest, brushwood and other forest products, selective agricultural production, hydrotechnological interventions aimed at the improvement of hydrological conditions, reintroduction of the autoch- 
thonous plant and animal species, tourism with the controlled movement.

The Special Nature Reserve „Stari Begej - Carska bara” is looked after by the Fishing Farm "Ečka" from Lukino selo.

\section{Anthropogenic Influence on the Special Nature Reserve "Stari Begej - Carska bara"}

Strong influences on the basic physiognomy of the landscape and geographic features of this part of Banat began in the $19^{\text {th }}$ century, resulting in the change of the morphology of the terrain and changes of the water regime. The building of the embankment, as the microform of anthropogenic relief has prevented the flood wave of Begej, as well as Tisza, to the ecologically important ecosystems. Similarly in other parts of Vojvodina, the embankments were elevated as the preventive protection of the surrounding settlements from the overflown rivers, but also for the drainage of soil in order to increase the area of arable land. The embankment separates the banks of Stari Begej and Carska Bara from Farkaždinski Rit and Botoški Rit on the north. It was built in the beginning of the $20^{\text {th }}$ century (Ham, 1975). With the digging of the new route of Begej (Begejski kanal - Plovni Begej), new embankments were built as protection from high water. This time they had a significant influence on the territory of the present Special Nature Reserve "Stari Begej - Carska bara", whose territory, by that time, had completely been surrounded by embankment. Ham (1975) states that total isolation of the area was completed in 1974, because at the time part of the new embankment was finished by the village of Perlez. The last flood years of the area were in 1972 and 1973 .

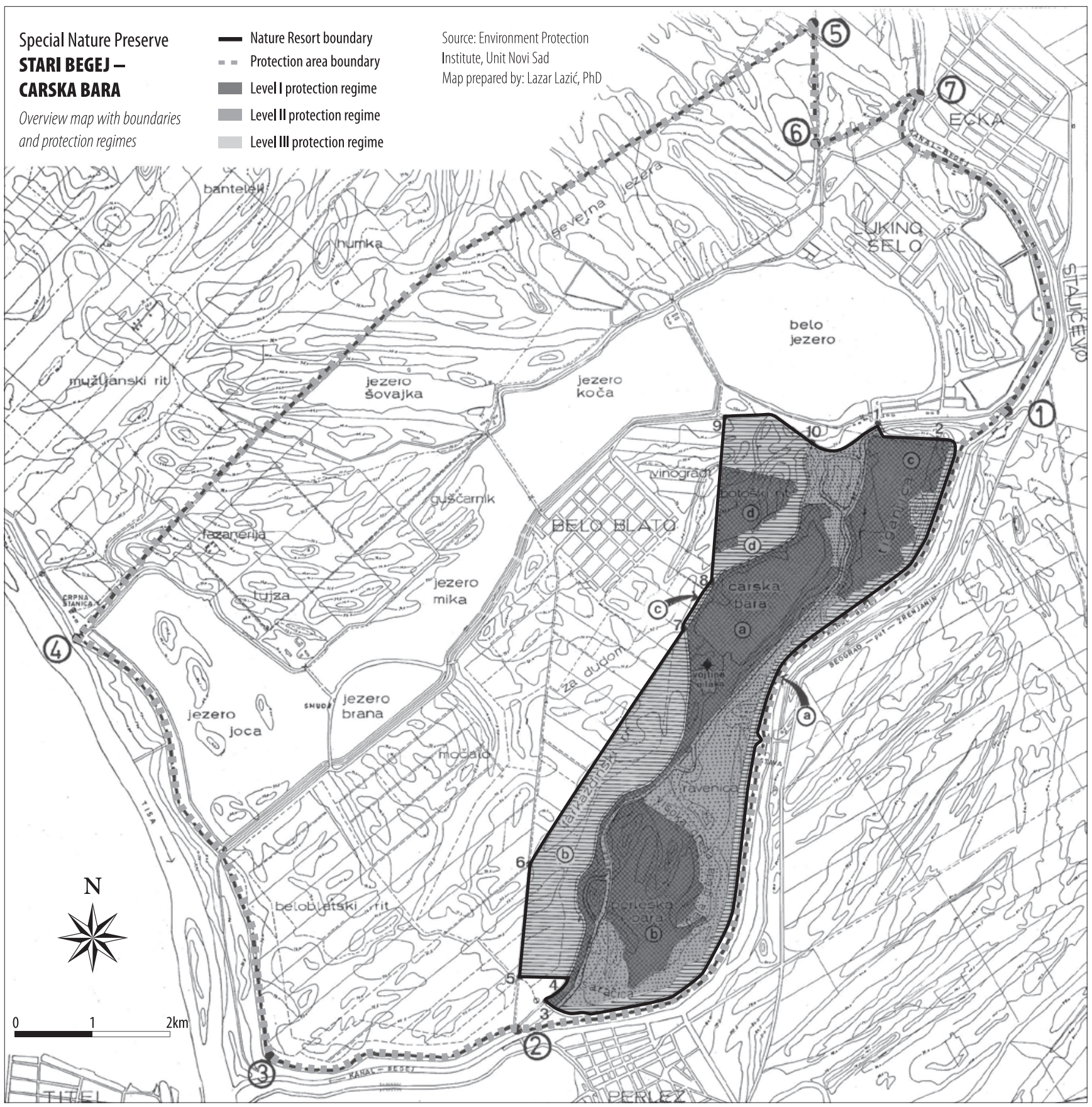

Figure 2 Protected zone distribution of a Special Nature Reserve "Stari Begej-Carska bara" 


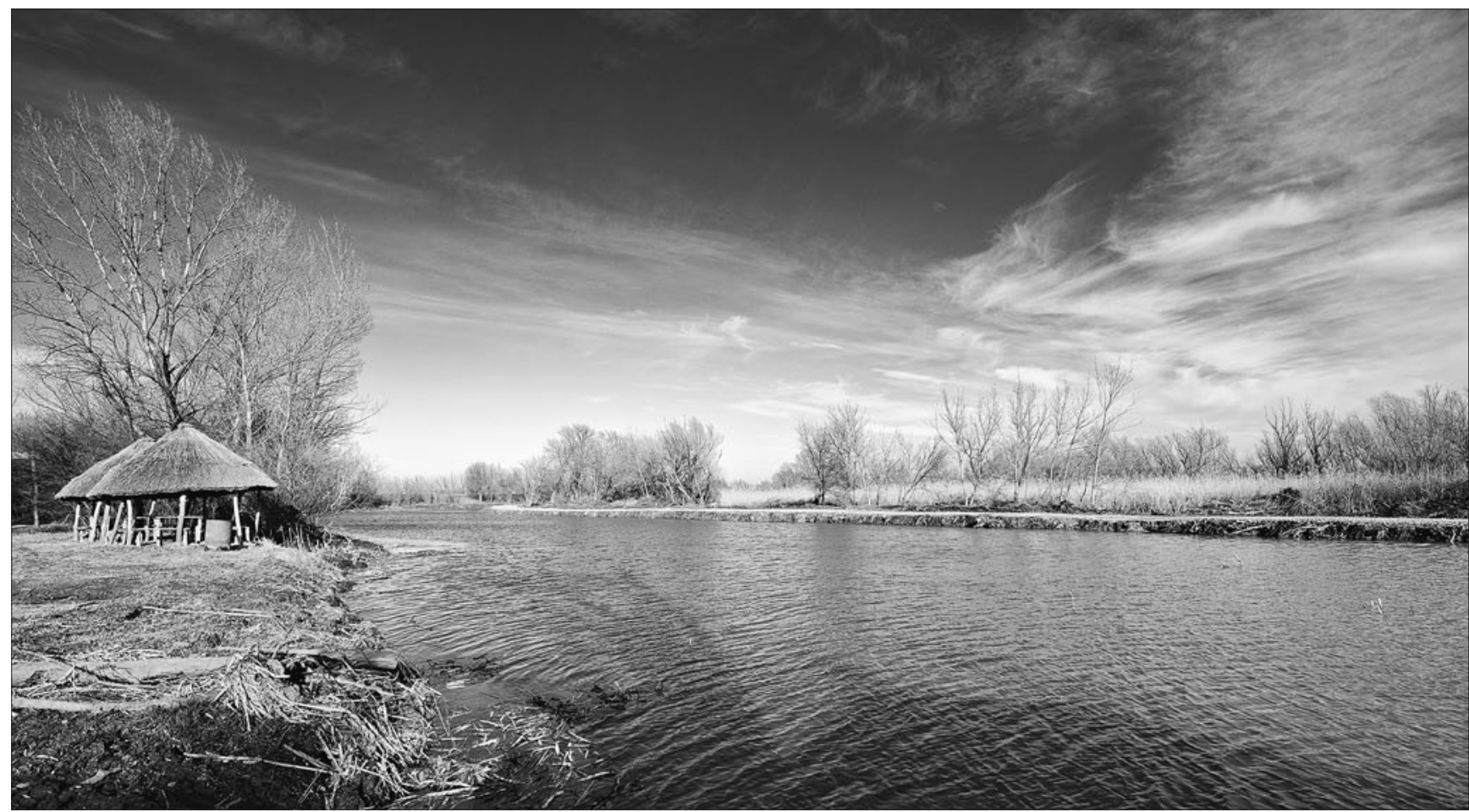

Figure $\mathbf{3}$ Stari Begej - for ecosystem preservation it is necessary to remove sludge; Photo by: L.Lazić

Before the embankment. this entire area was flooded by high waters of Tisza and Begej. This would happen when water was above $340 \mathrm{~cm}$. In view of this, ecological consequences of the embankment became evident, and today they are manifested through the more intensive drainage of the area.

Significant changes in ecosystems happened through the digging of the new waterbed of Begej. The works began in the mid-196os within the project of the hydro system DanubeTisza - Danube. The Begej Canal was made navigable in 1971. At the time the enclosure of the waterbed was completed near the present Hotel Sibila, and the tributary near the mouth of Tisza was completely blocked. This changed the water regime. The covering of Tiganjica and Perleska Bara with the dug soil had especially negative effects on the original features of the region, which made them shallow and caused a decrease in the depressions. In a few years time, the entire areas were covered in willows and swam macrophytes. A boundary was made on the south part of Stari Begej, near Perlez, which connected the old and the new embankment (Ham, 1975). Those changes in the surface hydrography of the current Special Nature Reserve, probably had a significant impact on the underwater which is not only influential on the total hydrological characteristics of the region, but also on its biogeographic characteristics.

The investigation of the state and quality of water in Stari Begej show that this waterbed is burdened with several ecological problems. The general quality of water in Stari Begej is extremely poor. According to the water quality parametres, it is close to third degree, which in addition to relatively shallow water and heavy microphyte vegetation, shows that Stari Begej from eutrophic state is turning into a marsh, and according to the degree of saprobity it is becoming a highly polluted water. In addition to water, mud is also of bad quality. Its quantity is larger, which endangers the survival of this significant waterbody, which represents a habitat of numerous plant and animal species. In addition to natural resourc- es, which lead to the destruction of Stari Begej, the mudding is also supported by the water from the fish ponds, rich in organic matter. The problem of mudding is most significant near the fish pond pump, downward $700 \mathrm{~m}$.

Because of this, in order to preserve this natural asset, the management of the Special Nature Reserve "Stari Begej - Carska bara" has started the initiative of the clearance of the waterbed near Stari Begej starting from the fish pond pump. The clearing would be conducted in the combined way with dry land and navigation machinery. The removed mud would be from 1.5 to $2 \mathrm{~m}$ (Proposal for technical solution for sludge removal, 2003). The realization of the project is being prepared currently.

Although Plovni Begej is not within the border area of "Stari Begej - Carska bara", its water flow can be of great influence for the preservation of the ecosystem. Numerous research has shown that Plovni Begej is rather polluted. On the territory of Zrenjanin this river receives waste water from the industrial plants, which influences the state of the lower water flow. The pollution of this river is a grave social problem. This excludes the possibilities for the optimum usage of available resources. The problem is even graver, because the polluted river water permeates and pollutes the underground phreatic water. This is the essential danger of the Plovni Begej to the Special Nature Reserve "Stari Begej Carska bara", whose eastern border it flows along.

\section{Local communities and sustainable development}

The settlements along the Special Nature Reserve "Stari Begej-Carska Bara", which has around 12000 inhabitants (Table 1), mainly have a decreasing trend in population numbers. The total population number has been decreased for 356 . The increasing trend in the analysed period, was recorded in 1953, 1961 and 1981. Comparing the first and 
Table 1 Population numbers in the surroundings of the Special Nature Reserve "Stari Begej-Carska bara" after World War Two

\begin{tabular}{|l|r|r|r|r|r|r|r|}
\hline & 1948 & 1953 & 1961 & 1971 & 1981 & 1991 & \multicolumn{1}{c|}{2002} \\
\hline Belo Blato & 2.159 & 2.490 & 2.031 & 1.841 & 1.746 & 1.762 & 1.477 \\
\hline Stajićevo & 1.133 & 1.299 & 1.413 & 1.607 & 1.903 & 2.061 & 1.999 \\
\hline Perlez & 4.528 & 4.623 & 4.881 & 4.458 & 4.283 & 3.888 & 3.818 \\
\hline Ečka & 3.934 & 4.188 & 4.323 & 4.621 & 5.293 & 5.177 & 4.513 \\
\hline Lukino selo & 1.007 & 757 & 876 & 722 & 703 & 652 & 598 \\
\hline Ukupno & 12.761 & 13.357 & 13.524 & 13.249 & 13.928 & 13.540 & 12.405 \\
\hline
\end{tabular}

the last year in the analysed period, three settlements had a depopulating character - Belo Blato, Perlez and Lukino selo. The highest population fall was in Perlez for 710 . The population numbers in Ečka show an increase if compared to 1948 , but when compared to 1981 , they show a significant fall for -780 . Similar situation is evident in Perlez and Stajićevo.

Economic activity in this area is mainly related to agriculture, but in individual situations it is also connected to the Reserve, as a prevailing ecosystem. Fishing is developed along the rim of the Special Nature Reserve "Stari Begej Carska bara". To the north of its borders, there are ponds fish ponds, owned by the Fish Farm "Ečka". This establishment is also the Manager of the Special Nature Reserve, and its basic activity is fishing. In the Proposal for the protection of "Stari Begej - Carska bara" (1993), it was characterized as potentially risky for the protected water ecosystems. Some of the problems in the past period were successfully solved. In the village of Belo Blato, there are two factories for reeds manufacturing. Reeds, as raw material, is most often exploited in the vicinity of Special Nature Reserve "Stari Begej - Carska bara" (Stojanović, 2005). In cases of some other reserves in Vojvodina, it has been recorded that reeds exploitation can be important for the protection, because reeds with its biomass and production buries some swamps to a certain extent, and in the foreseeable future can completely bury them and dry them out. (Information about conditions, protection and possibility for the sustainable use of protected nature area "Stari Begej-Carska bara", 2000). Finally, a significant incentive from the local community, government and management has been given to tourism development, especially ecotourism and sustaina- ble tourism as an important element in the protection and promotion of nature. The opening of the ethno-center in Belo Blato is of special importance, because it has caused the increase of excursions coming in.

Local communities represent important elements for the idea of sustainable tourism. In accordance to this, are the questions about the level of awareness about natural assets, protection and usage of the protected areas. According to large scale surveys about the attitudes of the local population on the sample of five Special Nature Reserves in Vojvodina (Gornje Podunavlje, Koviljsko-petrovaradinski rit, Stari Begej-Carska bara, Obedska bara and Karađorđevo) the following data have been established. The largest number of participants is aware that the areas of Carska bara, Stari Begej and the vicinity are protected as natural asset. However, this population category is the least informed about the degree of the protection, with only $7 \%$ of the participants being aware of the correct answer. At the same time, they often think that Stari Begej and Carska bara are protected as national parks. The reasons should be looked for in the publicity materials about the Reserve, which contained the identical mistake for years. In the group of five Reserves, talking about illegal activities in the protected area, the population is most informed in the settlements around Special Nature Reserve "Stari BegejCarska bara". $60 \%$ of the participants could name correctly or partially correctly those activities. This population is also well-informed about the natural assets of the area, out of which $60 \%$ could name correctly or partially correctly those assets. At the same time, the participants were given freedom to name those assets - plant species, animal species, backwater, swamp, lake etc. (Stojanović, 2005).

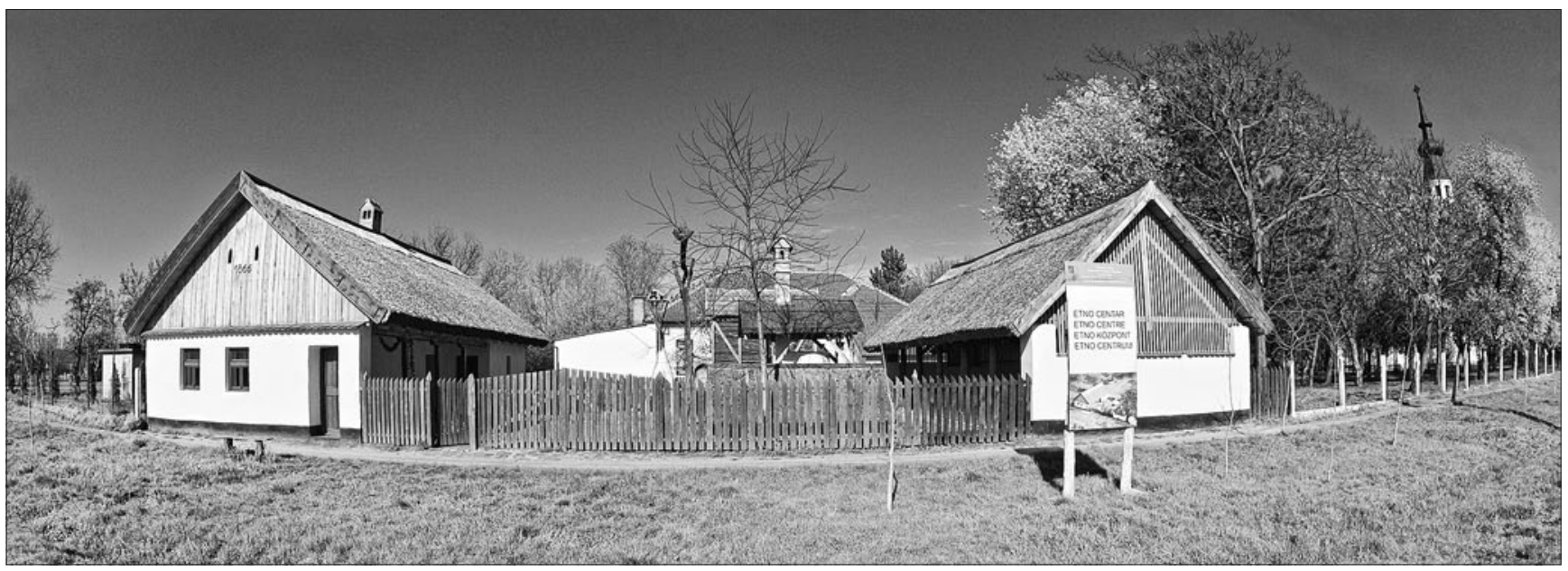

Figure 4 Ethno centre in Belo Blato; Photo by: L.Lazić 
Finally, it is important to mention a large number of participants in the settlements around the Reserve who are ready to learn more about the protected natural assets through media or in the other suggested way.

\section{Conclusion}

The initiative about the protection of the Special Nature Reserve was confirmed more than fifty years ago. In the period, the greatest improvement was made in the protection and presentation of the area. Today, this concept of protection should include criteria of sustainable development, i.e. the part that is related to local community and economy. In order to make progress it is necessary to take into account the following:

- Analysis and the application of such management criteria which will contribute to the preservation of essential natural features of the Reserve, especially hydrological and relief-related.

- Educating local communities about the basic natural features of the protected natural assets and their environment;

- Incentive to the economic development related to the assets of the Reserve, expecially to ecotourism;

- Promotion of natural and cultural assets of the Reserve and its surroundings, in order to make basic information available reagionally and nationally.

\section{Acknowledgements}

The research was supported by the Ministry of Science of the Republic of Serbia (project no. 146019)

\section{Reference}

Budakov, Lj., Banjac, M., Branković, D., Butorac, B., Habijan-Mikeš, V., Ham, I., Kovačev, N., Kovačević, B., Kuzmanović J., Mikeš, B., Pavkov, G., Stojšić, V., ViderMilošević, V. 1993. Proposal for natural protection of „Stari Begej-Carska bara“. Institute for Nature Conservation of Serbia, Novi Sad. (in Serbian)

Budakov, Lj., Branković, D., Sekulić, N. 1998. Special nature reserve "Stari Begej-Carska bara”, flora and fauna wildlife. Institute for Nature Conservation of Serbia, Novi Sad. (in Serbian)

Ham, I. 1975. Qualitative structure of the heron colony (Ardeidae) and the influence of individual environmental factors on its formation in the area of Lower Begej in Vojvodina. Larus 26 - 28, Zagreb. (in Serbian)

Information about conditions, protection and possibility for the sustainable use of protected nature area „Stari Begej-Carska bara“, Republic of Serbia, Autonomous Province of Vojvodina, Government of the Autonomous Province of Vojvodina, Novi Sad, 200o. (in Serbian)

Proposal for technical solution for sludge removal, Fishing Farm Ečka, Lukino selo, 2003. (in Serbian)

Stojanović, V. 2005. Sustainable development in Special Nature Reserves in Vojvodina. Department of Geography, Tourism and Hotel Management, Faculty of Science, Novi Sad. (in Serbian)

Stojanović, V., (2005): Degradation and Protection of Wetlands in Special Nature Reserves in Vojvodina, Geographica Pannonica, vol. 9, $24-28$.

Tomić, P. 1992. Fishpond Ečka. DD Fishing Farm, Lukino selo. (in Serbian) 